not wholly successful. Fully comprehensive coverage of such a large field is not to be expected, even in a thousand pages, but the balance between different topics is in places very uneven. Only a handful of articles, for example, make any reference to the soluble components of the cytoplasm, but nearly half of the books (surely too much) is devoted to cytoplasmic fila- ments. These volumes do however contain a wealth of interesting material, while the breadth of ground covered makes them especially valuable to more general readers, or to cell biologists exploring areas peripheral to their own.

Harriet Harris is at the Laboratory of Molecular Biology, Cambridge, UK.

\section{Tectonics: moving with the times}

\author{
Janet V. Watson
}

Plate Tectonics and Crustal Evolution, 2nd Edn. By Kent C. Condie. Pp.310. Hbk ISBN 0-08-028076-5; pbk ISBN. 0-08-028075-7. (Pergamon: 1982.) Hbk $£ 32.50, \$ 65$; pbk $£ 13.10, \$ 29.50$.

So MANY books have been written in the aftermath of the plate tèctonic upheaval that any new arrival is bound to encounter some resistance. Kent Condie's volume is a second edition, issued six years after the original, and can therefore be said to have already justified its existence.

Has the new edition moved with the times? Although text, figures and tectonic map have been updated with respect to many details, my impression is that the book retains not only the merits but also the defects of its predecessor. Kent Condie is distinguished for his work on Precambrian magmatic assemblages, and his treatment of the Precambrian magmatic provinces and of igneous phenomena generally is thorough and effective. He is successful in showing how geophysical and geochemical data can contribute to the understanding of geological problems and he has been unusually courageous in his attempts to elicit a general picture from the scrappy and often contradictory evidence about the deep structure of the crust and mantle. The numbers assigned to such values as the average thicknesses of crust in different types of province make good Aunt Sallys for the knowledgeable, though the less-experienced reader might have been better served if a range rather than an average had been quoted.

The inequalities of standard of treatment seem more apparent in this second edition than they did in 1976. In particular the disparity between the sophisticated discussion of magmatic phenomena and the cursory treatment of sedimentary basins has become more glaring. The author justifies the omissions on the reasonable grounds of lack of space and on the need to avoid overlap with other published works. Nonetheless, plate tectonics without the sedimentation story is Hamlet with no more than half the Prince of Denmark.

I have one final personal regret which concerns the otherwise welcome world tectonic map which is contained in a pocket at the back of the book. Maps are not only valuable sources of information, they can also be objects of beauty that kindle the imagination and stimulate the ininitiated and the expert alike; this one succeeds in its first role but is sadly deficient in the second.

Janet Watson is a Professor in the Department of Geology at Imperial College, University of London. 